\title{
ANALISIS KELAYAKAN BISNIS RESTORAN CHICKEN CRUSH TUASAN MEDAN
}

\author{
Sabda Dian Nurani Siahaan ${ }^{1 *}$, Novita Indah Hasibuan ${ }^{1)}$ \\ 1) Fakultas Ekonomi, Universitas Negeri Medan

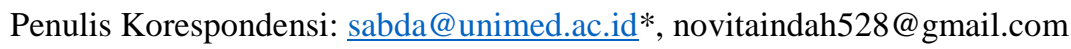

\begin{abstract}
Abstrak
Sebuah studi kelayakan bisnis diperlukan untuk mengetahui gambaran tentang kemungkinan sebuah bisnis untuk dijalankan. Penelitian ini bertujuan untuk mengetahui apakah restoran Chicken Crush yang terletak di Tuasan, Medan layak dijalankan atau tidak. Setiap aspek yang menjadi indikator dalam studi kelayakan bisnis harus memenuhi standar tertentu, namun penilaian tidak hanya dilakukan pada satu aspek saja. Penilaian untuk memutuskan kelayakan harus didasarkan pada beberapa aspek. Metode analisis yang digunakan dalam penelitian ini adalah metode penelitian deskriptif berdasarkan aspek-aspek Studi Kelayakan Bisnis, yaitu, Aspek Hukum, Aspek Pasar dan Pemasaran, Aspek Teknis/Operasi, Aspek Manajemen \& SDM, Aspek Ekonomi, Sosial dan Politik dan Aspek Analisis Mengenai Dampak Lingkungan (AMDAL). Hasil penelitian ini menunjukkan bahwa restoran Chicken Crush, Tuasan Medan layak untuk dijalankan dan memiliki prospek yang bagus.
\end{abstract}

\section{Keywords : Chicken Crush, Studi Kelayakan Bisnis}

Informasi Artikel:

Artikel Diterima: 8 Mei 2021

Artikel Direvisi: 4 Juni 2021

Artikel Disetujui: 16 Juni 2021 


\section{PENDAHULUAN}

Ayam goreng merupakan salah satu produk hasil olahan ternak ayam yang telah menjadi makanan favorit oleh hampir sebagian besar masyarakat di Indonesia. Usaha penjualan ayam goreng merupakan salah satu jenis usaha yang memiliki prospek bisnis yang sangat bagus karena produk ini relatif disenangi oleh hampir semua segmen umur, mulai anak-anak, remaja, maupun dewasa. Saat ini terdapat beberapa franchise yang menawarkan ayam goreng sebagai menu utama, seperti Kentucky Fried Chicken (KFC), McDonald's, Allen \& Wright $(A \& W)$, dan California Fried Chicken (CFC), dsb. Di Indonesia, pasar dari ayam goreng dengan balutan tepung ini dikuasai oleh beberapa waralaba besar tersebut.

Kota Medan yang terkenal dengan kulinernya memiliki banyak franchise ayam goreng selain yang disebukan di atas mulai dari yang berskala kecil yaitu yang dijual dijalanan, hingga yang berskala besar seperti, TOP Fried Chicken, Quality Fried Chicken, Quick Chicken, Chicken Crush, dsb. Uniknya franchise-franchise tersebut menawarkan produk utama yaitu ayam goreng dengan balutan tepung. Hal tersebut menunjukkan bahwa ayam goreng adalah makanan yang sangat diminati oleh masyarakat.

Dalam meningkatkan penjualan produk, bisnis restoran ayam goreng sangat bergantung pada selera konsumen. Oleh karena itu pemahaman atas kebutuhan dan selera konsumen sangatlah penting. Kepuasan atas pelayanan dapat menjadikan konsumen menjadi loyal dan berpotensi untuk melakukan pembelian ulang. Penyajian produk ayam goreng yang konsisten enak menjadi salah satu permasalahan yang dihadapi oleh para produsen atau pemilik restoran ayam goreng. Berbagai macam metode telah diterapkan untuk memperoleh ayam goreng yang enak dan empuk diantaranya pemasakan yang lama dengan suhu tinggi sampai dengan penggunaan enzim pengempuk.

Pengembangan bisnis produksi ayam goreng membutuhkan analisis yang matang untuk menghasilkan laba semaksimal mungkin. Kesuksesan dalam berbisnis dapat diperoleh melalui pertimbangan yang matang dan pemenuhan terhadap beberapa aspek Studi Kelayakan Bisnis, yaitu Aspek Hukum, Aspek Pasar dan Pemasaran, Aspek Keuangan, Aspek Manajemen dan SDM, Aspek Sosial, Ekonomi dan Politik, dan Aspek Analisis Mengenai Dampak Lingkungan (AMDAL) (Sulastri, 2016). Semua aspek tersebut saling berhubungan dan usaha yang sehat adalah usaha yang memenuhi persyaratan dari ketujuh aspek tersebut. Analisis kelayakan suatu bisnis merupakan sebuah kajian terhadap rencana bisnis yang menganalisis layak atau tidak layaknya bisnis tersebut dibangun, dan juga saat dioperasionalkan secara rutin dalam rangka pencapaian profit yang maksimal untuk waktu yang tidak ditentukan (Afiyah, 2015). Analisis kelayakan dapat dijadikan sebagai sumber laporan tertulis kepada pihak-pihak yang membutuhkan, dalam hal ini pemilik modal dan mitra kerjanya. Analisis kelayakan juga dapat dipergunakan sebagai sebuah syarat 
dalam pengajuan kredit pada lembaga keuangan (Lapia et al., 2017).

Kelayakan sebuah usaha merupakan hal yang serius untuk diperhatikan dan dianalisis sebab analisis kelayakan usaha bertujuan mengetahui apakah suatu usaha layak dijalankan atau tidak, apakah memenuhi kriteria studi kelayakan, baik dari aspek produksi, aspek hukum, dsb. Jika sebuah usaha tidak layak berdasarkan aspek-aspek studi kelayakan, maka dapat menimbulkan dampak negatif terhadap berbagai pihak khususnya masyarakat atau konsumen. Misalnya, dari segi aspek hukum, sebuah usaha harus memiliki izin pendirian dan izin edar yang resmi, jika tidak maka produk yang dihasilkan oleh usaha tersebut dapat membahayakan masyarakat. Dengan demikian, kelayakan suatu usaha merupakan hal yang sangat penting untuk dianalisis, baik sebelum memulai usaha dan juga setelah usaha didirikan.

Dalam penelitian ini, penulis tertarik untuk melakukan penelitian mengenai "Analisis Studi Kelayakan Bisnis Fried Chicken (Studi Kasus Pada Chicken Crush Tuasan, Medan)". Restoran Chicken Crush tersebut berada di Jln. Tuasan No. 38 Medan, dan restoran ini sudah memiliki 3 (tiga) cabang di berbagai wilayah di kota Medan. Pemilihan atas objek penelitian tersebut karena waralaba ini masih tergolong baru, sedang cukup populer dan dikunjungi oleh para konsumen dari semua segmen. Pemilihan lokasi di Tuasan juga merupakan karena restoran ini memiliki daya tarik tersendiri. Di depan restoran disajikan tulisan besar bertuliskan
Chicken Crush, warna gedung yang khas yaitu merah juga menarik perhatian. Dengan demikian, tujuan penelitian ini adalah untuk menganalisis tingkat kelayakan restoran Chicken Crush, Tuasan dari segi aspek non finansial yaitu Aspek Hukum, Aspek Pasar dan Pemasaran, Aspek Manajemen, Aspek Sosial dan Ekonomi, dan Aspek Analisis Mengenai Dampak Lingkungan (AMDAL).

\section{TINJAUAN PUSTAKA}

\section{Studi Kelayakan Bisnis}

Studi kelayakan bisnis adalah suatu kegiatan yang menganalisis secara mendalam dan utuh tentang suatu kegiatan atau usaha yang akan dijalankan, untuk menentukan layak atau tidaknya suatu bisnis atau kegiatan dijalankan (Jakfar, 2012). Berdasarkan pengertian tersebut dapat disimpulkan bahwa analisis studi kelayakan dibutuhkan sebelum memulai usaha untuk menentukan apakah usaha tersebut layak dijalankan atau tidak. Analisis studi kelayakan bisnis diperlukan bukan hanya untuk rencana bisnis melainkan juga untuk menganalisis suatu bisnis saat dioperasikan atau dijalankan. Tujuan dilakukannya analisis studi kelayakan adalah untuk menghindari resiko kerugian, memudahkan perencanaan, memudahkan pelaksanaan pekerjaan, memudahkan pengawasan, dan memudahkan pengendalian. Aspek-aspek dalam Studi Kelayakan Bisnis diantaranya Aspek Hukum, Aspek Pasar dan Pemasaran, Aspek Keuangan, Aspek Manajemen, Aspek Sosial dan Ekonomi, dan 
Aspek Analisis Mengenai Dampak Lingkungan (AMDAL) (Jakfar, 2012).

\section{Aspek Hukum}

Tujuan dari aspek hukum adalah untuk meneliti keabsahan, kesempurnaan dan keaslian dari dokumen - dokumen yang dimiliki (Sulastri, 2016). Pemeriksaan keabsahan dokumen dapat dilakukan oleh lembaga yang mengeluarkan dan yang mengesahkan dokumen - dokumen milik perusahaan. Indikator kelayakan suatu usaha jika ditinjau dari aspek hukum adalah apakah usaha tersebut legal secara hukum atau tidak. Keabsahan dokumen suatu usaha juga dapat digunakan sebagai jaminan jika usaha tersebut ingin melakukan pinjaman.

\section{Aspek Pasar dan Pemasaran}

Aspek pasar dalam studi kelayakan bisnis membahas mengenai besarnya permintaan penawaran dan harga (Yanuar, 2016). Pemasaran merupakan upaya untuk memproduksi dan menjual produk kepada para konsumen dengan maksud tertentu. Dalam aspek pasar dan pemasaran, hal penting yang harus diperhatikan adalah Bauran Pemasaran atau Marketing Mix, yaitu penyaluran dan komunikasi nilai-nilai pelanggan (Costumer Value) kepada pasar. Ada empat komponen dari Bauran Pemasaran atau Marketing Mix untuk masuk ke pasar, yaitu perusahaan memiliki produk yang bagus dan sesuai dengan target pasar (Product). Sebuah produk tersebut harus memiliki harga yang sesuai dengan kemampuan target pasar (Price). Keberhasilan memasuki pasar juga ditentukan oleh wilayah atau lokasi (Place) dan melalui strategi promosi (Promotion) yang tepat agar produk yang ditawarkan dapat diterima sesuai dengan target pasar.

Suatu usaha atau bisnis dikatakan layak dari aspek pasar, apabila usaha tersebut memiliki peluang dan potensi pasar yang bagus untuk memasarkan produk yang dihasilkannya.

\section{Aspek Teknis dan Operasi}

Hal-hal yang diperhatikan dalam aspek ini adalah masalah penentuan lokasi, luas produksi, tata letak (layout), penyusunan peralatan pabrik, dan proses produksinya termasuk pemilihan teknologinya (Syarbaini, 2015). Selain itu, hal-hal yang perlu diperhatikan dalam aspek lokasi mengenai lokasi usaha, baik kantor pusat, cabang, pabrik, atau gudang.

Indikator kelayakan suatu usaha berdasarkan aspek teknisnya, yaitu apakah usaha tersebut menjalankan usahanya sesuai dengan Standard Operation Procedure (SOP). Jika perusahaan telah menjalankan usaha sesuai SOP, maka usaha tersebut layak secara aspek teknis, dan sebaliknya.

\section{Aspek Manajemen dan SDM}

Suatu usaha tidak dapat berjalan dengan baik tanpa didukung oleh manajemen dan organisasi yang baik. Didalam aspek manajemen hal yang perlu dianalisis adalah perencanaan, pengorganisasian, pelaksanaan, dan pengawasan dengan baik untuk mencapai tujuan perusahaan atau organisasi tersebut. Aspek manajemen dan Sumber Daya Manusia (SDM) menganalisis tahap-tahap pelaksanaan atau pengorganisasian bisnis dan kesiapan tenaga kerja, baik tenaga kerja kasar maupun 
tenaga kerja terampil yang diperlukan untuk menjalankan bisnis dalam suatu organisasi atau perusahaan (Purnomo et al., 2018).

Aspek manajemen dan SDM sangat penting untuk dianalisis karena dalam sebuah organisasi, masing - masing departemen memiliki keterkaitan satu dengan yang lainnya sehingga dibutuhkan suatu komando yang jelas dan tegas. Suatu organisasi dapat diibaratkan seperti tubuh karena semua bagian dan semua pihak memiliki keterkaitan satu dengan yang lainnya. Suatu usaha dapat dikatakan layak dari aspek manajamen dan SDM apabila usaha tersebut telah menjalankan fungsi manajemen yang menjadikan usaha tersebut lebih efektif dan efisien.

\section{Aspek Ekonomi, Sosial dan Politik}

Dalam aspek ini yang perlu diperhatikan adalah apakah usaha atau proyek yang dijalankan memberikan manfaat secara ekonomi dan sosial kepada berbagai pihak atau sebaliknya (Syarbaini, 2015). Tujuan utama perusahaan adalah mencari keuntungan yang sebesarnya-besarnya. Namun, perusahaan tidak dapat hidup sendirian. Perusahaan hidup dengan komponen lain dalam satu tatanan kehidupan yang pluralistis dan kompleks, walau hendaknya selalu berada dalam keseimbangan. Suatu usaha dapat dikatakan layak ditinjau dari aspek sosial dan ekonomi apabila usaha tersebut dapat memberikan benefit ataupun manfaat kepada negara umumnya dan masyarakat sekitar proyek khususnya.

Selain itu, adanya isu atau rumor yang timbul akibat kondisi politik yang diciptakan pemerintah akan mempengaruhi permintaan dan penawaran suatu produk yang ditawarkan suatu perusahaan, baik itu produk barang maupun jasa. Dalam studi kelayakan bisnis hendaknya memperkirakan situasi politik saat bisnis dibangun dan dijalankan agar tidak mengganggu sehingga kajiannya menjadi layak.

\section{Aspek AMDAL (Analisis Dampak Lingkungan Hidup)}

Lingkungan hidup merupakan salah satu aspek yang sangat penting untuk diperhatikan dan ditelaah sebelum suatu usaha atau proyek dilaksanakan. Perubahan ini jika tidak diantisipasi dari awal akan merusak tatanan yang sudah ada, baik terhadap fauna, flora, maupun manusia itu sendiri.

Dalam studi kelayakan bisnis jika mendirikan perusahaan untuk investasi bisnis diperlukan kesepakatan/perjanjian tertulis maupun tidak tertulis dalam proses pembangunnya dimana perjanjian ini adalah perjanjian untuk menjaga lingkungan hidup. Sisa buangan atau sampah dari proses pengolahan pun harus dipastikan agar tidak merusak dan mencemari lingkungan dan harus dinetralkan agar tidak mencemari lingkungan atau membahayakan masyarakat di sekitar lokasi usaha. Indikator suatu usaha dikatakan layak ditinjau dari segi AMDAL dilihat dari dalam menjaga lingkungan dan penanggulangan pencemaran lingkungan.

\section{METODE PENELITIAN}

Penelitian ini dilaksanakan di Restoran Chicken Crush di Jl. Tuasan No.38, Sidorejo 
Hilir, Medan Tembung, Kota Medan (Simpang Tempuling) pada Maret 2021. Objek dalam penelitian ini adalah restoran Chicken Crush cabang Tuasan. Adapun ruang lingkup penelitian ini yakni Analisis kelayakan usaha pada restoran Chicken Crush yang ditinjau dari aspek non finansial yaitu aspek hukum, aspek pasar dan pemasaran, aspek teknis dan operasi, aspek manajemen dan organisasi serta SDM, aspek ekonomi sosial, dan politik serta aspek AMDAL.

Metode yang digunakan dalam penelitian adalah metode kualitatif dan selanjutnya disajikan dalam bentuk analisis deskriptif. Teknik pengumpulan data dalam penelitian ini adalah dengan teknik interview (wawancara) kepada informan, yaitu kepala bagian personalia dan beberapa karyawan franchise Chicken Crush cabang Tuasan, observasi dan dokumentasi.

Data yang digunakan dalam penelitian terdiri dari data primer yaitu yang diperoleh langsung dari observasi atau wawancara dengan pemimpin atau manajer serta karyawan franchise Chicken Crush mengenai aspek aspek dalam studi kelayakan bisnis.

\section{HASIL DAN PEMBAHASAN}

Chicken Crush adalah merek ayam geprek kekinian yang punya banyak level kepedasan dan berbagai macam sauce. Restoran Chicken Crush didirikan pada April 2017 dan outlet pertama berada di Yogyakarta. Hingga saat ini, outlet Chicken Crush sudah tersebar di beberapa kota di Indonesia diantaranya berada di kota Madiun, Malang,
Semarang, Magelang, Serpong, Batam, Medan, dsb. Di Medan, outlet Chicken Crush berdiri pada Februari 2019 dan memiliki 3 cabang yaitu di berada di Jln Tuasan, Jln Willem Iskandar, dan Jln Karya Clincing.

\section{Aspek Hukum}

Pendirian dan beroperasinya suatu usaha diakui keberadaannya oleh pemerintah jika berbentuk badan usaha dan memiliki perizinan usaha. Kelengkapan dan keabsahan dokumen sangat penting karena ini merupakan dasar hukum yang harus dipegang apabila dikemudian hari timbul masalah.

Setiap cabang restoran Chicken Crush sudah memiliki dokumen dan surat resmi terkait dengan pendirian dan operasional usaha. Perizinan usaha yang dimiliki usaha Chicken Crush adalah (1) akta pendirian; (2) Tanda Daftar Perusahaan (TDP) ; (3) Surat Izin Usaha Perdagangan (SIUP) ; (4) surat keterangan domisili usaha; (5) Nomor Pokok Wajib Pajak (NPWP); (6) Izin Mendirikan Bangunan (IMB), serta sertifikat - sertifikat atau surat - surat berharga lainnya. Dokumendokumen tersebut sudah tersedia sebelum restoran dibuka.

(Sa'id et al., 2020) dalam penelitiannya mengenai Analisis Kelayakan Usaha Produksi Tahu Sumedang, menyimpulkan bahwa usaha Tahu Sumedang tersebut telah mememuhi syarat berdasarkan aspek hukum karena telah memiliki dokumen yang lengkap seperti Surat Keterangan Domisili Usaha (SKDU), Izin Prinsip, dan Tanda Daftar Perusahaan (TDP). Berdasarkan hal tersebut maka dapat disimpulkan bahwa 
Chiken Crush Tuasan layak dari aspek hukum sebab dokumen-dokumen untuk perizinanperizinan usaha sudah terpenuhi dan dikeluarkan oleh lembaga yang sah.

\section{Aspek Pasar Dan Pemasaran}

Konsep pemasaran yang terapkan oleh restoran Chicken Crush Tuasan Medan menekankan proses penjualan dari produsen kepada konsumen. Sistem tersebut bertujuan untuk memperoleh laba dan keuntungan dengan menggunakan sistem bauran.

\section{a) Marketing Mix}

\section{Product}

Chicken Crush merupakan restoran ayam goreng krispi dan renyah yang telah hadir sejak Maret 2017. Menu utama yang disajikan Chicken Crush bukan sekedar ayam goreng namun dengan sentuhan lokal yaitu ayam geprek dengan berbagai toping modern. Para konsumen dapat menikmati sensasi ayam goreng khas western dengan sambal khas Indonesia.

Aneka makanan yang ditawarkan restoran Chicken Crush Cabang Tuasan seperti Ayam Geprek, Rice Box, Milk Shake, Burger Chicken Donnut, Mie Gotan, dsb. Bahkan saat ini Chicken Crush Cabang Tuasan sedang mengembangkan strategi pemasaran produk yang baru yaitu dengan menjual Frozen Chicken. Frozen Chicken ini terbagi dalam 2 kategori yaitu Frozen Chicken Meat dan Frozen Chicken Skin. Alasan franchise Chicken Crush Tuasan membuat inovasi produk atau New Product adalah untuk memperluas target dan pangsa pasar mereka.

\section{Price}

Harga yang ditawarkan Chicken Crush cabang Tuasan juga sangat terjangkau dengan namun tetap memiliki kualitas yang mampu bersaing. Untuk harga produk restoran Chicken Crush antara lain :

1. Kategori Produk Rice Box = Rp. $12.000-$ Rp. 15.000,00.

2. Kategori Produk Chicken Crush Super Hemat $=$ Rp. 12.000,00.

3. Kategori Produk Chicken Crush Skin Chicken $=$ Rp. 10.000,00.

4. Kategori Produk Chicken Crush Double Cheese $=$ Rp. 25.000,00.

5. Kategori Produk Chicken Crush Duo Keju $=$ Rp. $25 \cdot 000,00$.

6. Kategori Chicken Crush Kids + Ice Cream $=$ Rp. $20.000,00$.

7. Kategori Produk Duo Geprek = Rp. 22.000,00.

8. Kategori Produk Kentang Goreng + Cheese $=$ Rp. 15.000,00.

9. Kategori Quorto Chicken Crush = Rp. 44.000,00 - Rp. 60.000,00.

10. Kategori Mie Gotan Chicken Crush = Rp. 10.000,00.

11.Kategori Burger Chicken Donnut $=$ Rp. 10.000,00.

12.Kategori Frozen Chicken Crush $=$ Rp. 40.000,00 - Rp. 50.000,00.

Berdasarkan daftar harga menu yang ditawarkan tersebut, dapat disimpulkan bahwa Restoran Chicken Crush Tuasan, Medan menawarkan harga yang sangat terjangkau bagi semua kalangan. Masih ada beberapa menu makanan yang ditawarkan di Restoran 
Chicken Crush selain yang di atas, dan tentu saja dengan harga yang terjangkau.

\section{Place}

Chicken Crush telah memiliki 35 cabang outlet diberbagai kota di Indonesia. Salah satu cabang dari Chicken Crush ini adalah di kota Medan tepatnya di Jalan Tuasan (Simpang Tempuling). Chicken Crush Tuasan ini memiliki konsep balutan container yang membuat Chicken Crush tuasan berbeda dengan fried chicken lainnya disekitar daerah tersebut. Lokasi Chicken Crush Tuasan ini juga sangat strategis jaraknya dekat dengan kampus dan tempat tinggal masyarakat lingkungan sekitar, yang membuat Chicken Crush Tuasan ini semakin hari semakin ramai.

\section{Promotion}

Promosi yang digunakan oleh restoran Chicken Crush selama ini adalah media poster, brosur atau selebaran, dan media online. Karena promosi dilakukan melalui media poster dan brosur, para karyawan Chicken Crush dapat terjun langsung membagikan poster atau brosur kepada masyarakat lingkungan sekitar. Ketika ada promo atau diskon yang menggiurkan dari masyarakat akan antusias mendatangi restoran Chicken Crush Tuasan dan menikmati semua menu yang tersedia. Setiap event yang diadakan oleh restoran Chicken Crush Tuasan pasti akan menawarkan promosi atau diskon. Untuk media online, Chicken Crush Tuasan membagikan segala aktivitas pemasarannya di website mereka yaitu di www.chickencrush.id dan kalau untuk dimedia sosial yaitu di
Instagram, Facebook, dan Twitter yaitu @chickencrush_tuasan.

\section{b) Segmenting, Targeting and Positioning \\ 1. Segmenting}

Segmentasi konsumen yang dituju oleh Chicken Crush Tuasan dibagi menjadi 3 yaitu geografis, demografis, dan psikografis.

a. Geografis : wilayah dan kepadatan penduduk.

b. Demografis : gender, pendapatan, generasi, umur, serta status sosial.

c. Psikografis : gaya hidup dan benefits.

\section{Targeting}

Berdasarkan dari hasil segmentasi maka restoran Chicken Crush bisa menarget konsumen secara spesifik.

a. Geografis

Wilayah yang menjadi target dari Chicken Crush Tuasan adalah kota Medan dan sekitarnya, terutama daerah Tuasan dan sekitarnya. Namun Chicken Crush Tuasan juga menerima orderan dari luar kota sama seperti dengan outlet Chicken Crush lainnya.

b. Demografis

Berdasarkan hasil segmentasi maka target konsumen Chicken Crush Tuasan adalah anak - anak, remaja, dewasa, bahkan orangtua. Namun kebanyakkan konsumen yang datang dan menikmati menu - menu di Chicken Crush adalah mahasiswa atau pemuda pemudi yang saat ini sedang hits dengan zaman (milenial). Restoran Chicken Crush ini menjadi tempat tongkrongan bagi mereka. Sasaran Chicken Crush Tuasan adalah kelas atas, kelas menengah dan kelas 
bawah. Siapapun bisa menikmatin Chicken

Crush Tuasan. Chicken Crush Tuasan

Terbuka untuk semua kalangan.

c. Psikografis

Gaya hidup dan ingin makanan cepat saji, murah dan baik untuk kesehatan. Ketiga hal tersebut merupakan pola pikir yang saat ini ada pada kalangan anak muda atau anak milenial zaman sekarang. Mereka ingin mencari suatu tempat makan, yang hits, murah, cepat saji, dan baik untuk kesehatan. Chicken Crush Tuasan menawarkan semua itu dan merangkumnya menjadi satu. Chicken Crush Tuasan memenuhi isi pikiran anak - anak muda zaman sekarang.

\section{Positioning}

Chicken Crush sudah memiliki positioning yang sangat menempel di ingatan dan hati para konsumennya, terutama konsumen kategori mahasiswa (anak - anak muda zaman sekarang). Apalagi Chicken Crush juga memiliki slogan yang selalu dibuat di pintu masuknya yaitu Every Day Wakeup, Every Work, Everyday Chicken Crush. Dari slogan tersebut semua orang tahu bahwa Everyday Is Chicken Crush Only Chicken Crush. Selain murah, Chicken Crush juga memiliki suasana atau spot foto yang menarik yaitu container tersebut. Setiap produk atau setiap menu makanan pada Chicken Crush diberikan Es Teh sepuasnya bagi setiap pemesanan, dimana es teh ini diambil sendiri oleh konsumen, dan konsumen bisa mengisi kembali minumannya, dilokasi yang telah disediakan oleh Chicken Crush Tuasan. Ini merupakan strategi yang membuat Chicken
Crush Tuasan semakin melekat dihati konsumen.

Berdasarkan penjabaran mengenai aspek pasar dan pemasaran pada Chicken Crush Tuasan ini, yang dibahas dalam Bauran Pemasaran, Segmenting, Targeting, dan Positioning maka dapat disimpulkan bahwa Chicken Crush Tuasan ini layak untuk dijalankan dan dikembangkan. (Handjojo \& Syarief, 2017) dalam penelitiannya mengenai Analisis Kelayakan Bisnis Usaha Teh Papua juga menganalisis sistem bauran pemasaran yang digunakan oleh usaha teh Papua tersebut dalam menentukan layak tidaknya suatu usaha berdasarkan aspek pasar dan pemasaran. Dengan menggunakan sistem bauran pemasaran (marketing mix) yang baik, maka teknis pasar dan pemasaran suatu usaha akan tertata dengan baik dan tepat sasaran.

\section{Aspek Teknis/Operasi}

Kelayakan bisnis restoran Chicken Crush Tuasan, Meda dapat dilihat dari lokasi usaha, luas produksi, layout atau tata letak ruangan, dan pemilihan teknologi yang digunakan. Jika dilihat dari teknis lokasi, restoran ini layak dijalankan karena berada di pinggir jalan raya, juga berada di sekitar tempat tiggal masyarakat serta tempat tinggal kontrakan mahasiswa, dekat dengan lokasi Pasar Sore Tuasan, adanya tenaga listrik dan air yang dibutuhkan untuk operasional usaha, tersedianya tenaga kerja, terjaminnya sumber daya yang dibutuhkan dan akses yang mudah untuk menjangkau lokasi restoran. Berdasarkan hasil wawancara dengan kepala bagian personalia dan karyawan Chicken 
Crush Tuasan, pertimbangan tersebutlah yang menjadi alasan membuka usaha ini adalah karena cabang Chicken Crush dikota Medan yang berlokasi di Tuasan, mengingat juga cabang Chicken Crush di Medan masih sedikit. Untuk kesesuaian luas produksi yang dipertimbangkan adalah bagaimana kapasitas untuk peratan serta lay out dari tata letak, apakah mampu menghasilkan kinerja yang lebih efektif dan efisien serta memperkecil tingkat kecelakaan kerja.

(Sa'id et al., 2020) dalam penelitiannya yang berjudul Analisis Kelayakan Usaha Pabrik Tahu Sumedang juga menggunakan indikator yang sama untuk menentukan layak tidaknya usaha Tahu Sumedang tersebut berdasarkan aspek teknis dan operasi. Usaha Tahu Sumedang tersebut dikatakan layak berdasarkan aspek teknis dan operasi karena lokasinya strategis dan efektif untuk menjangkau target pasar, bahan baku, tenaga kerja, fasilitas yang memadai di lokasi tersebut serta adanya dukungan dari masyarakat dan pemerintah setempat.

\section{Restoran Chicken Crush Tuasan}

Medan juga memiliki tata letak/layout yang efektif. Berikut tata letak produksi Chicken Crush Tuasan:

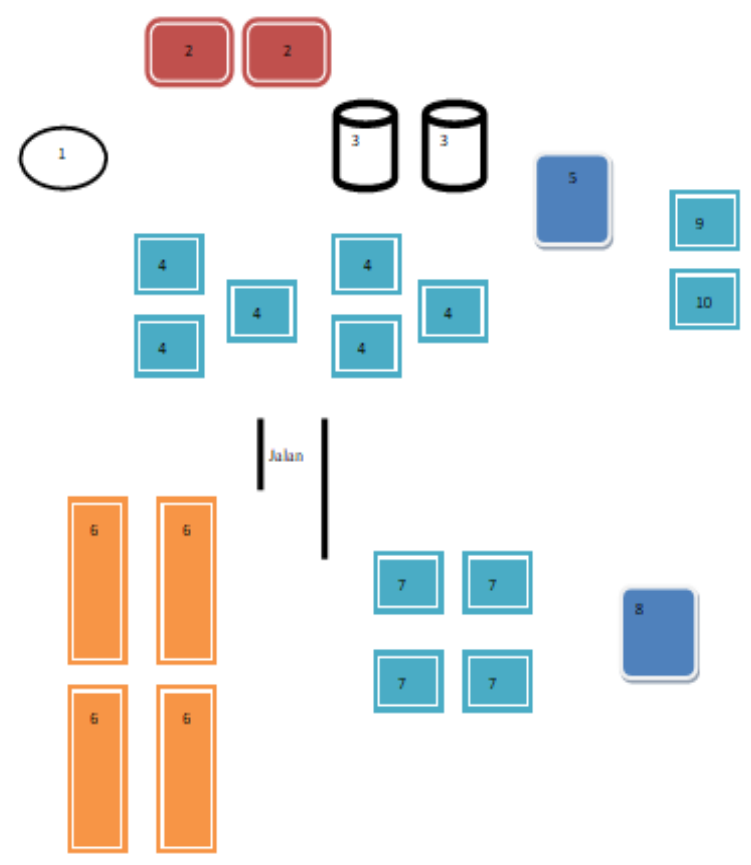

Gambar 1. Tata Letak Restoran Chicken Crush Tuasan

Keterangan layout Chicken Crush Tuasan :

(1) = Pintu Masuk Chicken Crush

(2) = Bagian Kasir

(2) $=$ Bagian Produksi/Pembuatan Makanan

(3) = Bagian untuk mengambil air minum (air teh) yang disediakan

(3) = Bagian untuk mengambil air minum (air teh) yang disediakan

(4) = Meja Makan Konsumen Chicken Crush Tuasan

(5) = Tempat Cuci Tangan Untuk Bagian Depan Chicken Crush Tuasan

11 = Jalan / lorong menuju meja makan konsumen berikutnya

(6) = Meja Makan Konsumen Chicken Crush Tuasan Bagian Samping

(7) = Meja Makan Konsumen Chicken Crush Tuasan Bagian Samping

(8) $=$ Tempat Cuci Tangan Untuk Bagian Samping Chicken Crush Tuasan

(9) = Toilet Wanita 
(10) $=$ Toilet Pria

Dilihat dari hasil layout tersebut dapat dkatakan Chicken Crush Tuasan dalam aspek teknis dan operasi dapat dikatakan layak untuk diteruskan, pemilik ataupun para karyawan dapat melakukan inovasi dalam membuat layout yang lebih baik atau lebih sempurna lagi sehingga usaha Chicken Crush Tuasan ini semakin sukses kedepannya.

\section{Aspek Manajamen Dan SDM}

Aspek manajemen dan organisasi adalah salah satu aspek yang penting dalam suatu perusahaan. Dimana semua aktivitas operasional kerja maupun dalam produksi akan lebih terarah dan efektif jika sudah ada sistem manajemen yang baik.

Dalam perencanaan untuk tugas dan tanggung jawab karyawan sudah ada perencanaan yang khusus maupun pada perencanaan yang memiliki SOP. Hal yang paling diutamakan pada Chicken Crush Tuasan adalah tentang kejujuran serta etos kerja yang baik.

Untuk pelaksanaan kerja, pemilik menuturkan bahwa sudah ada SOP dan sudah dibuat secara tertulis dan dipatenkan. Akan tetapi SOP tersebut masih dalam bentuk pengawasan oleh pemilik serta dibantu oleh setiap kepala bagian dalam Chicken Crush Tuasan terutama kepala bagian personalia. Beberapa SOP yang harus dipatuhi pada restoran Chicken Crush diantaranya yaitu:

a. Jam buka Chicken Crush Tuasan mulai pukul 10.00 pagi - 11.00 malam. b. Dari jam 07.00 -09.00 pagi, adalah kegiatan untuk produksi ayam dan segala persiapan untuk membuka restoran.

c. Persiapan untuk operasional kerja oleh karyawan.

d. Menyiapkan peralatan dan perlengkapan.

e. Membersihkan tempat dan segala persiapan untuk membuka restoran.

f. Memperhatikan dan menjaga untuk kesehatan dan keselamatan kerja.

g. Melayani para konsumen dengan sopan dan ramah tamah.

h. Kebersihan personal harus diperhatikan dalam melayani konsumen.

Pengawasan yang dilakukan oleh pemilik Chicken Crush Tuasan berupa pengawasan langsung karena pemilik pun ikut membantu dalam operasional kerja. Kemudian dalam satu minggu sekali diadakan evaluasi untuk mengontrol kinerja karyawan. Namun jika pemilik sibuk atau ada kendala untuk memantau langsung maka tugas tersebut akan diserahkan pemilik kepada kepala bagian. Jadi, kepala bagian akan memberikan laporan kepada pemilik bisa secara langsung ketika pemilik datang ke lokasi atau melalui virtual.

Untuk aspek Sumber Daya Manusia (SDM), berdasarkan hasil analisis wawancara bersama kepala bagian personalia untuk aspek Sumber Daya Manusia (SDM), maka dari mulai perencanaan pengadaan SDM, rencana seleksi sampai orientasi berbanding positif dengan hasil temuan wawancara bersama karyawan restoran Chicken Crush Tuasan. Begitupun dengan indikator Sumber Daya Manusia (SDM) yang lainnya seperti 
kompensasi, pengembangan, pelatihan serta pemaliharaan kesehatan dan keselamatan kerja terhadap karyawan.

(Afiyah, 2015) dalam penelitiannya mengenai Analisis Studi Kelayakan Usaha Pendirian Home Industry, menemukan bahwa Home Industry tersebut layak dijalankan sebab memiliki struktur organisasi yang sederhana dan menerapkan sturktur organisasi garis (lini) yang menunjukkan pemilik usaha berupaya untuk menjalin hubungan dan kerja sama yang baik dengan karyawan. Selain itu, Home Industry tersebut juga mengadakan pelatihan secara rutin kepada karyawannya walaupun bersifat non formal. Secara keseluruhan, restoran Chicken Crush sudah memenuhi kriteria tersebut. Dengan demikian, dari segi aspek manajemen dan SDM, restoran Chicken Crush Tuasan sudah baik dan layak untuk dikembangkan lebih lanjut.

\section{Aspek Ekonomi, Sosial Budaya, Dan Politik}

Dalam aspek ekonomi hal yang dilihat adalah bagaimana kontribusi suatu usaha terhadap lingkungan sekitarnya. Dengan dibukanya restoran Chicken Crush Tuasan ini cukup membantu masyarakat untuk membuka kesempatan kerja serta dapat menumbuhkan industri lain seperti menumbuhkan supplier lokal dalam pengadaan bahan baku. Berdasarkan hasil wawancara bersama kepala bagian personalia bahwa dengan dibukanya usaha ini cukup berpartisipasi menciptakan lapangan kerja baru. Untuk saat ini karyawan Chicken Crush Tuasan sebagian besar merupakan warga asli daerah kota Medan dan masyarakat daerah Tuasan. Tentu hal ini dapat membantu untuk meningkatkan mutu hidup karyawan tersebut.

Hal yang senada ditemukan oleh (Fitriani et al., 2018) dalam penelitiannya yang berjudul Studi Kelayakan Bisnis Bakso Lotus Jember. Dalam penelitian tersebut, usaha Bakso Lotus Jember memberikan dampak ekonomi yang baik bagi masyarakat karena dengan memberikan peluang kerja kepada masyarakat. Suatu usaha layak untuk dijalankan jika memiliki kontribusi yang positif bagi masyarakat.

Restoran Chicken Crush Tuasan juga rutin mengadakan event atau kegiatan yang berkaitan dengan promosi. Pada setiap event, restoran akan membagikan beberapa kotak salah satu menu Chicken Crush Tuasan kepada masyarakat disekitar lingkungannya, ataupun kepada orang yang membutuhkan. Kepala bagian personalia mengatakan bahwa pada bulan suci Ramadhan di bulan April, pemilik restoran Chicken Crush Tuasan telah melakukan kegiatan amal ke salah satu panti asuhan yang ada di kota Medan yaitu Panti Asuhan Ade Irma Suryani, dimana beliau mengamalkan 500 kotak beberapa menu dari restoran. Beliau juga memberikan 100 kotak kepada salah satu mesjid yang berada didaerah lokasi Chicken Crush Tuasan berdiri. Kegiatan ini sosial ini dilakukan agar Chicken Crush Tuasan selalu semakin didepan dan selalu maju, serta selalu diingat oleh masyarakat baik dihati dan dipikiran.

Untuk aspek politik, berdasarkan hasil analisis dengan mewawancarai kepala bagian personalia dan sebagian karyawan, mereka 
menuturkan bahwa jika ada muncul isu tentang ayam tiren maupun ayam busuk yang diolah menjadi ayam goreng itu akan mempengaruhi terhadap penjualan Chicken Crush tuasan. Penjualan bisa menurun. Namun solusi yang dilakukan untuk mengatasi hal tersebut adalah dengan tetap menjaga kepercayaan konsumen, yaitu dengan cara tetap menjaga rasa dan kualitas produk dengan agar tetap sama dan menjadi yang terbaik bagi para konsumen.

Berdasarkan hasil analisis diatas tersebut, studi kelayakan bisnis Chicken Crush Tuasan dari aspek ekonomi, sosial dan budaya, serta politik tersebut sudah dikatakan layak karena sudah berkontribusi positif terhadap ekonomi dan sosial masyarakat.

\section{Aspek AMDAL (Analisis Dampak Lingkungan Hidup)}

Aspek Lingkungan adalah suatu pengkajian yang dikenal sebagai analisis mengenai dampak lingkungan (AMDAL) yang merupakan suatu mekanisme untuk mencapai kelestariaan lingkungan, aspek lingkungan meliputi limbah yang dihasilkan oleh proses produksi. Aspek ini dilakukan agar kualitas lingkungan tidak rusak dengan beroperasinya proyek - proyek industri.

Dalam Aspek AMDAL ini yang perlu diperhatikan adalah bagaimana suatu perusahaan menjaga lingkungan sekitarnya agar tetap hidup, bersih, dan terjaga.

Berdasarkan hasil wawancara dengan kepala bagian personalia Chicken Crush Tuasan dan beberapa karyawannya, mereka mengatakan bahwa Chicken Crush Tuasan membeli ayam yang sudah bersih dan sudah tidak ada bulunya atau dapat dikatakan membeli ayam yang sudah jadi. Restoran telah memiliki reseller ayam dari perternakan ayam secara langsung yaitu pada "Peternakan Ayam Kampung Sehat" yang beralamat di Jalan Padang Bulan, Selayang. Jadi. Chicken Crush Tuasan sudah menjalin kerjasama yang cukup lama dengan pemilik peternakan ayam kampong sehat tersebut, dan sudah memiliki kesepakatan bahwa ayam yang akan diberikan kepada Chicken Crush Tuasan adalah ayam yang sehat dan sudah dibersihkan bulu dan kotorannya. Jadi, restoran tidak perlu kerepotan lagi untuk membersihkan ayam tersebut, tinggal mengolah ayam tersebut menjadi menu makanan.

Restoran juga sangat menjaga kebersihan lingkungan. Setiap harinya setelah restoran tutup, beberapa karyawan yang sudah ditugaskan akan membuang sampah ke tempat pembuangan sampah. Hal tersebut dilakukan setiap hari untuk menjaga kebersihan lingkungan sekitarnya.

(Winantara et al., 2014) dalam penelitiannya yang berjudul Analisis Kelayakan Usaha Kopi Luwak di Bali menyimpulkan bahwa usaha Kopi Luwak tersebut memenuhi syarat berdasarkan aspek AMDAL. Hal itu karena usaha Kopi Luwak tersebut menghasilkan dampak lingkungan yang baik kepada masyarakat, walaupun masih ada dampak negatif yaitu pembuangan limbah yang sedikit mengganggu kenyaman masyarakat. Namun usaha Kopi Luwak tersebut bersedia menanggulanginya agar tidak 
mengakibatkan dampak negatif yang berkepanjangan bagi masyarakat.

Dari hasil analisis diatas, dapat disimpulkan bahwa studi kelayakan bisnis dalam aspek Analisis Dampak Lingkungan (AMDAL) pada Chicken Crush Tuasan sudah dikatakan layak, dan sudah memenuhi peraturan kebersihan pemerintah.

\section{KESIMPULAN DAN SARAN}

Kesimpulan

Berdasarkan hasil penelitian keseluruhan aspek - aspek studi kelayakan bisnis Chicken Crush Tuasan maka terdapat beberapa kesimpulan yaitu : Berdasarkan Aspek Hukum, restoran Chicken Crush Tuasan sudah layak karena usaha ini sudah memiliki dokumen dan surat berharga dalam usahanya, seperti SIUP, IMB, dan dokumen penting lainnya yang sudah dipatenkan juga oleh pemerintah Kota Medan.

Berdasarkan Aspek Pasar Dan Pemasaran, restoran Chicken Crush sudah layak, dan berada dalam kategori yang sangat baik. Chicken Crush Tuasan sangat teliti dalam memperhatikan pasar dan pemasarannya dan menerapkan sistem bauran pemasaran (Marketing Mix) yang tepat, karena bagi mereka itu juga merupakan kunci sukses dalam usaha mereka.

Berdasarkan Aspek Teknis/Operasi, restoran Chicken Crush sudah layak, karena tata letak setiap sudut ruangan dalam restoran ini sangat diatur dengan rapi, dengan balutan konsep container yang membuat keunikan dari usaha resto ini. Layout disusun dengan apik oleh pemilik sehingga mempermudah para karyawan dan para konsumennya dalam melakukan kegiatan pada restoran. Selain itu lokasi usaha yang strategis dengan berbagai pihak menjadikan usaha ini sangat layak untu terus dijalankan dan dikembangkan.

Berdasarkan Aspek Manajemen dan SDM, restoran Chicken Crush sudah layak karena dalam restoran ini, untuk perencanaan, pelaksanaan serta pengawasan dilaksanakan sesuai dengan SOP yang ditetapkan oleh pemilik restoran. Bahkan pemilik pun terjun langsung untuk mengawasi kerja para karyawannya dengan dibantu juga oleh para kepala bagian. Aspek manajemen SDM sudah dapat dikatakan layak dengan rekomendasi bahwa untuk kompensasi karyawan sebaiknya dapat didaftarkan untuk kompensasi yang sudah resmi demi menjamin kesejahteraan karyawan

Berdasarkan Aspek Ekonomi, Sosial Dan Budaya, restoran Chicken Crush Tuasan sudah layak karena Chicken Crush Tuasan cukup membantu masyarakat dilingkungan sekitar untuk membuka kesempatan kerja. Selain itu, Chicken Crush Tuasan ini sering melakukan kegiatan amal dengan membagikan produk dari restoran kepada orang yang membutuhkan seperti ke panti asuhan, mesjid disekitar lokasi, dan masyarakat yang membutuhkan disekitar lokasi.

Berdasarkan Aspek Analisis Mengenai Dampak Lingkungan (AMDAL), restoran Chicken Crush Tuasan sudah layak karena Chicken Crush Tuasan sangat memperhatikan lingkungannya. Bagi mereka kebersihan 
lingkungan merupakan kehidupan bagi mereka, karena jika lingkungan restoran bersih maka segala kegiatan pada restoran akan berjalan dengan lancar.

Dari keseluruhan aspek - aspek non finansial dalam studi kelayakan bisnis pada restoran Chicken Crush Tuasan ini, sudah layak untuk dilanjutkan dan dikembangkan.

Saran

Saran dalam penelitian ini adalah diharapkan adanya penelitian lanjutan dengan menambahkan Aspek Keuangan. Karena keterbatasan penelitian ini hanya 6 aspek saja yang diteliti yaitu aspek hukum, aspek pasar dan pemasaran, aspek teknis dan operasi, aspek manajemen dan organisasi serta SDM, aspek ekonomi, sosial dan budaya serta politik, dan aspek AMDAL.

Dengan demikian, semoga penelitian ini dapat menjadi referensi bagi peneliti yang lainnya dan menjadi panduan atau referensi bagi pengusaha - pengusaha baru yang akan merilis atau memulai usahanya, agar dapat melihat studi kelayakan bisnis usaha yang akan dijalankannya apakah layak atau tidak.

\section{REFERENSI}

Afiyah, A. (2015). Analisis Studi Kelayakan Usaha Pendirian Home Industry (Studi Kasus pada Home Industry Cokelat âCozyâ Kademangan Blitar). Jurnal Administrasi Bisnis S1 Universitas Brawijaya, 23(1), 85949.

Fitriani, I. N., Sudono, A., \& Handyastuti, I. (2018). Studi Kelayakan Bisnis Bakso Lotus Jembar. Gastronomy Tourism
Journal, 5(1), 1-11.

Handjojo, E. S., \& Syarief, R. (2017). Analisis Kelayakan Bisnis Usaha Teh Papua (Vernonia Amygdalina). MANAJEMEN IKM: Jurnal Manajemen Pengembangan Industri Kecil Menengah, 12(2), 145150.

Jakfar, K. (2012). Studi Kelayakan Bisnis. Jakarta: Kencana.

Lapia, S. H., Dzulkirom, M., \& Z.A, Z. (2017). Upaya Mengantisipasi Terjadinya Kredit Bermasalah ( Studi Kasus pada PT . Bank Rakyat Indonesia Unit Sawojajar Malang ). Jurnal Universitas Brawijaya, 51(2), 179-187.

Purnomo, R. A., Riawan, R., \& Sugiharto, L. (2018). Studi Kelayakan Bisnis. UNMUH Ponorogo Press.

Sa'id, N. A., Ma'ruf, A., \& Delfitriani, D. (2020). Analisis Kelayakan Usaha Produksi Tahu Sumedang (Studi Kasus Di Pabrik Tahu XY Kecamatan Conggeang). JURNAL AGROINDUSTRI HALAL, 6(1), 105-113.

Sulastri, L. (2016). Studi Kelayakan Bisnis untuk Wirausaha. LGM-LaGood's Publishing.

Syarbaini, A. (2015). Kelayakan Potensi Pengembangan Usaha Es Susu Jagung Manis (Zea Mays Sacc.). Jurnal Pertanian, 6(1), 21-34.

Winantara, I. M. Y., Bakar, A. B. U., \& Puspitaningsih, R. (2014). Analisis Kelayakan Usaha Kopi Luwak di Bali. Reka Integra, 2(3).

Yanuar, D. (2016). Analisis Kelayakan Bisnis 
Ditinjau dari Aspek Pasar, Aspek Pemasaran dan Aspek Keuangan pada UMKM Makanan Khas Bangka di Kota Pangkalpinang. Jurnal E-KOMBIS, II(1), 41-51. 